\title{
Development of an Epoxy Resin Bonded Explosive - Interim Report
}

\author{
P. Archibald
}

\section{DISCLAIMER}

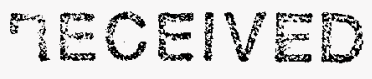

JAN 291997

This report was prepared as an account of work sponsored by an agency of the United States Government. Neither the United States Government nor any agency thereof, nor any of their employees, makes any warranty, express or implied, or assumes any legal liability or responsibility for the accuracy, completeness, or usefulness of any information, apparatus, product, or process disclosed, or represents that its use would not infringe privately owned rights. Reference herein to any specific commercial product, process, or service by trade name, trademark, manufacturer, or otherwise does not necessarily constitute or imply its endorsement, recommendation, or favoring by the United States Government or any agency thereof. The views and opinions of authors expressed herein do not necessarily state or reflect those of the United States Government or any agency thereof.

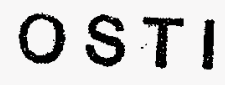

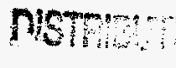

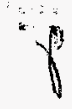

IS UMLIMITED

August 19, 1957

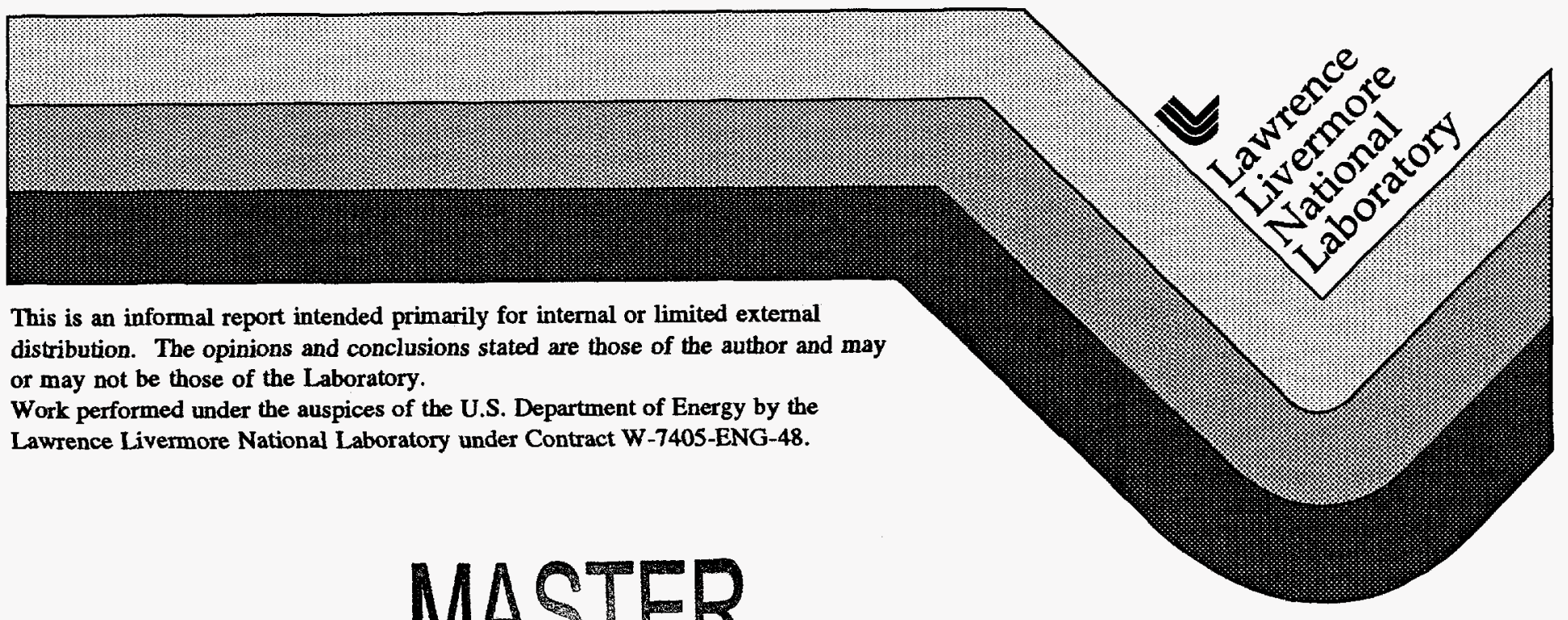




\section{DISCLAIMER}

Portions of this document may be illegible in electronic image products. Images are produced from the best available original document. 


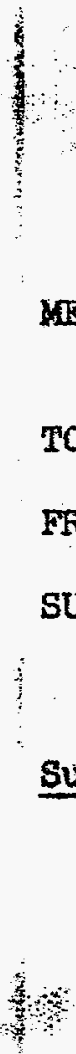

NAMO

TO:

FROM:

Barney Rubin/Gus Dorough

Paul Archibala

SUBJECT:

Interin Report on the Development of an Bpoxy ResIn Bonded Hxplosive

Sumary: This report sumbarlzes the work done to date on the development of an epoxy resin bonded explosive (MX). The original target values have been satisfied and further investigations will be on a semi-pilot plant scale.

The following characteriaties have been deterained on Iabof a tory apectinerin

\section{Target Value}

Compressive strength 10,000 psi 11-12,000 psi

Sensit1vity ( $50 \%$ height) Equivalent to Comp.B $31 \mathrm{~cm}$ whitch is $33.0 \mathrm{~cm}$.

Density gno /ec

1.80 or higher

1.81

Vacuum Stability (ce gas/ga/24 hrs. at

$.5 \mathrm{cc} / 24 \mathrm{hrs}$. $.42 \mathrm{cc} / \mathrm{gm}$ $\left.100^{\circ} \mathrm{C}\right)$

*Design of epoxy resin bonded HMX mixtures.

\section{Formulation:}

The optimu formulation developed consisted of $6 \%$ of the following resin mixture as a binder and $94 \%$ of ground FMX.

$\begin{array}{lr}\text { Epon } 828 & 70 \text { pts. } \\ \text { Versamide } 125 & 30 \text { pts. } \\ \text { DETA } & 7 \text { pts. }\end{array}$




Barney Rub 1n/Gus Dorough $\quad-2-1459 \quad 101$

The above binder formulation contains roca temperature catulyst. The pot I1fe of such a mixture is dependent to a considersble extent upon the mass of matertal involved and whether an exotherm will develop. Although a mass of 100 gms. in a container has a pot life of around one hour, when mixed with $\mathrm{BMX}$ in the amount of $6 \%$, the exotherm does not develop and the pot life is extended for several days. The use of such a catalyst reduces the press time to 10 minutes at $100^{\circ} \mathrm{C}$ instead of several hours ss is required by the oven curing catalysts.

\section{Preparation of Specimens:}

Specimens were produced by mixing intimately the catalyzed resin and HAX by grinding in a mortar and sereenting to break up aggregates. The powder which at this polnt agpears slightly damp is poured into the cold die and 30,000 psi 1e applied. The die $1 \mathrm{~s}$ then brought to $100^{\circ} \mathrm{C}$ and held for ten minutes. After cooling, the spectmen is extruded from the die. The specimen may then be post cured for several hours at $100^{\circ} \mathrm{C}$. (The optimum post cure has not been deternined, but it does not appear to be critical.)

While specimens of good mechanical strength can be wade by extruding the uncured epoxy HMX from a cold die and post curing, the density of such spectmens is around 1.78 instoad of 1.81 , which is obtainable by curing under pregsure.

The use of a vacum whlle presalng was not found to lncrease the density of specimens. It ws also determined that a double acting press, 1.e. one with ram movenent from both ends, produced. a stronger, denser specimen.

Paul Archibald

PA:

ce: distribution

Cop. $1 / 4 A$ - B. Rubin

2/4A - G. Dorough

B/4A - P. Archibald

4/4A - File

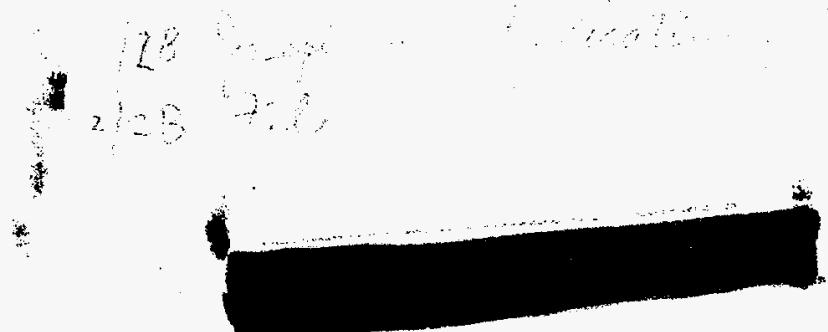

